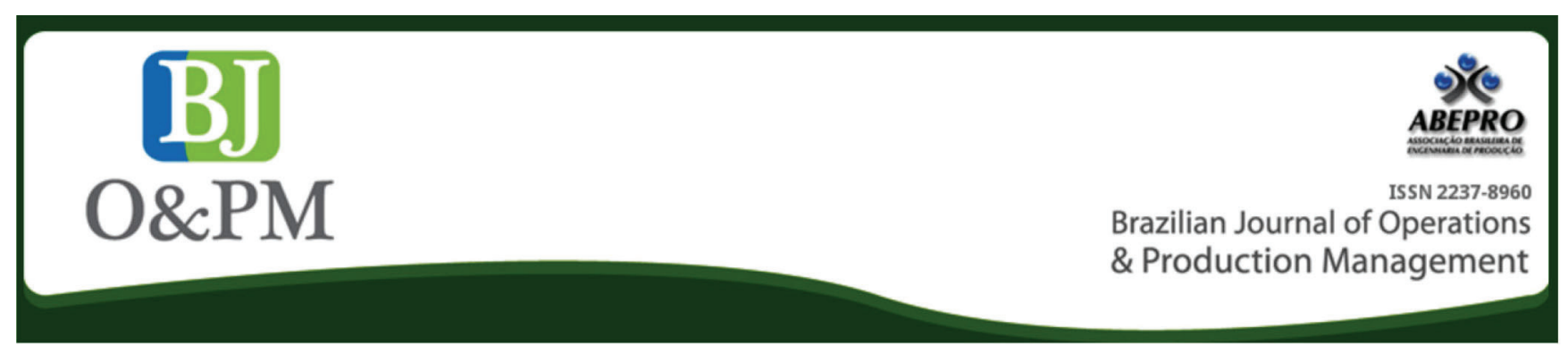

\title{
RESPONSES FROM INCUBATORS TO THE CREATIVE ECONOMY
}

\section{Julia Zardo}

juliaz@puc-rio.br

Gênesis Institute, Pontifical

Catholic University of Rio de

Janeiro - PUC-Rio, Rio de Janeiro,

Rio de Janeiro, Brazil.

\section{Ruth Mello}

ruth@puc-rio.br

Gênesis Institute, Pontifical

Catholic University of Rio de

Janeiro - PUC-Rio, Rio de Janeiro,

Rio de Janeiro, Brazil.

\begin{abstract}
The article analyzes the creative economy and how incubators around the world are managing to meet its needs. We chose as case studies the top 13 best incubators in the world according to UBI Index 2016 to demonstrate, again, the importance of the creative economy and corresponding responses from incubators. We focus especially on the case of the Genesis Institute, in Brazil which had to modernize itself to adapt to the emerging creative economy. From the research conducted, the following conclusions are reached: one, creative sectors are growing; and, two, it is necessary for incubators to adapt and meet these sectors' needs not only in Brazil but globally. Furthermore, it is possible to notice that certain incubators which have not developed creative sectors extensively will soon need to modernize, as their countries are already recognizing the importance of creative economy. Considering the incubators analyzed by this article and which have adapted to the emerging creative economy and its needs, it is considered that modernization is necessary to effectively serve startups.
\end{abstract}

Keywords: Creative Economy; UBI; Incubators; Startups. 


\section{METHODOLOGY}

The article attempts to track the responses of incubators to emerging startups of the creative economy through an analysis of the 13 top incubators in the world according to UBI Index (2016). In order to arrive to the responses mentioned and give the reader important context to the discussion the article wishes to foment, an introduction about what is the creative economy and its history was written first. After such, short analyses of the 13 classified incubators were placed by the 2016 UBI ranking and by the responses to emerging creative economies:

\section{SETsquared (United Kingdom)}

2. Innovation Incubation Center at Chaoyang University of Technology (Taiwan)

3. The DMZ at Ryerson University (Canada)

4. 1871 (United States)

5. PoliHub Startup District and Incubator (Italy)

6. Innovate Calgary (Canada)

7. INiTS Universitäres Gründerservice Wien $\mathrm{GmbH}$ (Austria)

8. ATP Innovations (Australia)

9. YES!Delft (Netherlands)

10. Uppsala Innovation Centre (Sweden)

11. UtrechtInc (Netherlands)

12. Huazhong University of Science and Technology National Science Park (China)

13. Instituto Gênesis (Brazil)

Following these analyses of responses of incubators to the creative economy, the Brazilian case is outlined, focusing especially on the Genesis Institute, which, due to the evolution of the creative economy in the country, had to be modernized and include this sector of the economy in order to meet its needs. Concluding with a comparative analysis, one expects the understanding on whether and how the development the Genesis Institute has also been experienced by other incubators around the world. In its totality, our study will define the importance of the creative economy as found by those of the best incubators in the world and also their impact on the development of their incubators and the enterprises of the sectors they serve.

\section{INTRODUCTION}

The term creative economy was first cited in 1994 in Australia during a debate about public policies which aimed to stimulate the economy through culture and creativity. In 1997, the British New Labor party quoted the term in its pre-election manifesto. Following the party's election and the implementation of several practices, including the mapping of economic sectors of the creative area covering other areas beyond the traditional culture, the term ended up spreading internationally (DCMS, 2001) and began to be incorporated in the documents of UNESCO and British Council in 2005.

However, although the subject is increasingly relevant internationally, its conceptual definition has not yet been consolidated. According to the United Nations Conference on Trade and Development (UNCTAD, 2008), there are differences among the definitions of creative industry used various countries, and even among intergovernmental bodies which establish some more widespread definitions. One of those definitions is that of Model of Symbolic Texts (Hesmondhalgh, 2002), which is used mainly by cultural industries. This model separates cultural activities into three areas:

1. Central Cultural Industries: Advertising; Movies; Internet; Music; Publishers; Television and radio; and Video and computer games.

\section{Peripheral Cultural Industries: Performing Arts}

3. Cultural industries without fixed distinction: Electronics, fashion, software and sports.

Another definition by UNCTAD is the Concentric Circles Model (Throsby, 2001), which is based on the notion that product differentiation occurs through the amount of cultural content, so that the more culture is used in the product, the greater the value of the product. This model, in turn, is best illustrated in a figure as seen below, in which the layers closer to the center have a greater cultural value and the more distant ones, a smaller value.

Finally, the last definition of interest the UK DCMS (United Kingdom Department of Culture, Media and Sport - DCMS, 2001), is used by the UK and inspired by its economic model. It is based on the idea that the creative industry uses skill, talent, and creativity to boost the economy and create jobs. According to them the creative industry includes: advertising, art and antiquity, crafts, design, fashion, movies, videos, music, performing arts, publishing, software, television, radio, and video and computer games. 


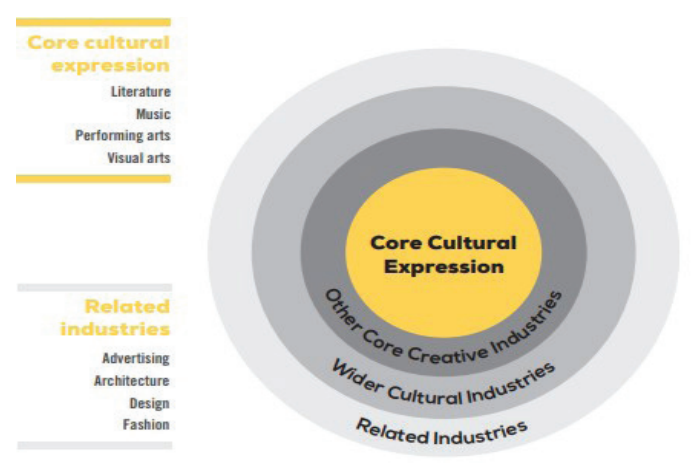

Figure 1. Concentric Circles Model

Source: Compiled from UNESCO Creative Economy Report, 2013.

Although the definitions outlined converge in some points, it can be observed that the terms still vary, mainly depending on the culture of the country, needs and demands of sectors. In Brazil, for example, we have one main definition, that is used by SEBRAE (Brazilian Service of Support to Small and Microenterprises) and FIRJAN (Industries Federation of the State of Rio de Janeiro), which divides the creative economy in four main sectors: Consumption (design, architecture, fashion, and advertising); Media (editorial and audiovisual); Culture (heritage and arts, music, performing arts, and cultural expressions) and Technology (R \& D, biotechnology, and ICT).

As demonstrated, there is no specific definition of creative economy, presumably due to the fact that it is a new sector, which is still rising. Despite the lack of a common definition, by comparing the definitions, it is noticed that, in general, all definitions and interpretations include similar areas, making the sought global analysis consequentially viable.

\subsection{The Creative Economy in the World}

Although the creative economy has only been recognized emerging since 1997, it has become more influential worldwide recently. Due to globalization and its technologies, the access to culture has expanded.

The image bellow, taken from a research made by UNESCO and the consulting group EY in 2015, which shows the amount of capital accumulated by the creative industry all over the world, demonstrates how this new sector is important to the global economy.

According to the information, the creative industry in Asia and the Pacific is the biggest in the world, corresponding to 743 billion dollars, the equivalent to $3 \%$ of the regional GDP, generating over 12.7 million jobs. After comes Europe's, which generates 709 billion dollars and 7.700.000 jobs. The third biggest is the North American, which has an annual revenue of 620 billion dollars and that generates 4.3 million jobs in the creative industry sector. That of Latin America and the Caribbean stand behind, and lastly, Africa and the Middle East's, considering how much it composes of its respective regional GDP.

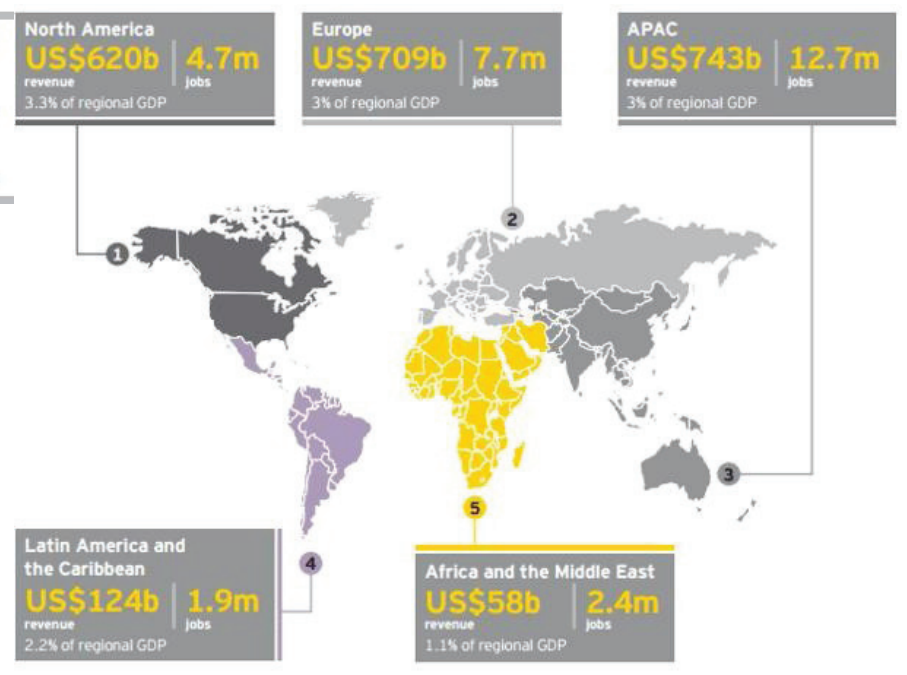

Figure 2. Cultural Times: the first global map of the creative industries

Source: EY, 2015

\subsection{Environments of Innovation in the Creative Economy}

According to Drucker (1997), the success of an entrepreneur depends, in addition to his capacity, on the environment in which he is inserted. The model of the Triple Helix, created by Etzkowitz and Leydesdorff (2000), also lists the environment, referring specifically to the relation between the actors and key economic agents of the same space, as an important factor for the emergence of innovations. This model identifies the interaction between three areas: academia, government, and business as essential. However, according to an article published by Miranda, Aranha and Zardo (2009), the "Triple Helix for Creative Entrepreneurship" differs slightly from the "Triple Helix" developed by Etzkowitz and Leydesdorff. According to them, so that the entrepreneurial actions in the branch occur, it is essential that there be innovative, entrepreneurial and amateur people at the center of creative production, a culture that brings these individuals around a common motive and, finally, an environment of innovation that helps to stimulate creativity, as shown in the image below.

Anprotec, as a final example, affirms that innovation environments encompass both the innovation areas (Science and Technology Parks, Intelligent Cities, Clusters, Innovation Districts, Innovation Communities, among others) and 
mechanisms of enterprise generation (Incubators of companies, Accelerators, Co-workings, Living Labs, and other mechanisms).

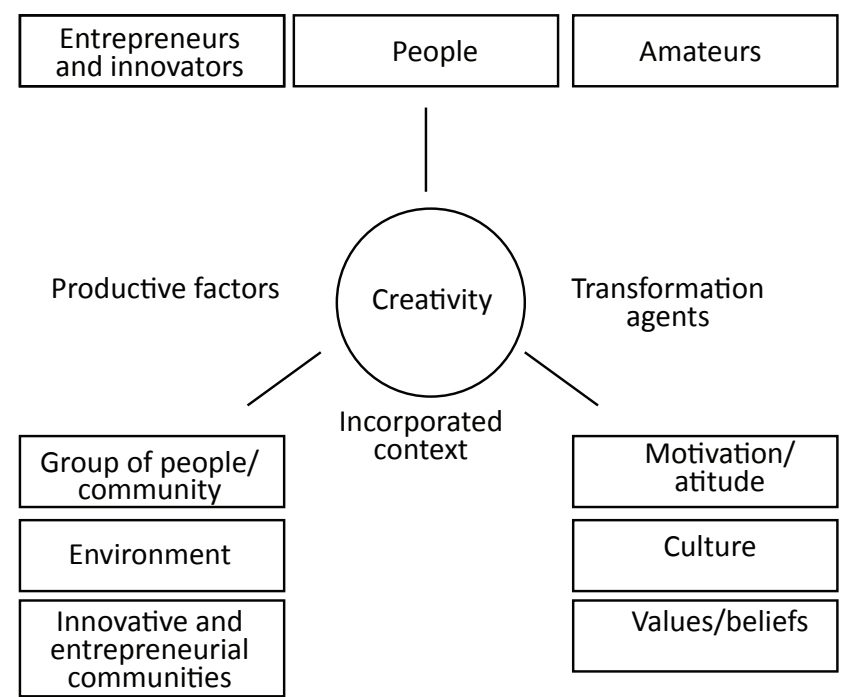

Figure 3. Triple Helix for Creative Entrepreneurship Source: Miranda; Aranha; Zardo, 2009

Taking into consideration that what is considered by the authors above is important to guarantee the success of the startups and new enterprises, the incubators assume some of the aspects considered as such. By providing support to their entrepreneurs' workspace, seed funding, mentoring, training, network, and other services, they provide the users of their services access to many of the topics listed in the "Triple Helix for Creative Entrepreneurship". Beyond that, some incubators are linked to universities, making it possible for them to also connect with the academia, as required by the "Model of the Triple Helix".

\subsection{The UBI}

The UBI is an organization that was created in Stockholm during 2013. Initially, it had as its main objective to connect and integrate universities and their incubators in order to collect data of its entrepreneurs and map the development, influence, and lifetime of the enterprises.

Nowadays, UBI aims to help accelerators and incubators to improve their performances. With its knowledge, UBI itself launched the UBI Index, which aims to analyze the quality of services provided by the incubators it chooses to analyze. The analysis criteria are: the value to the ecosystem, the value to the client (startups) and how attractive the incubating program is.
It is important to notice that the UBI Benchmarking Index has two categories: one analyzes incubators which are linked to universities, and the other compares the incubators that have no connection with academia.

\section{THE TOP 13 INCUBATORS}

It is intended, in this part of the article, to analyze the importance of the creative economy for the incubators that are linked to universities and composed the top 13 ranking of UBI in 2016.

The Gênesis Institute, from Brazil, which was ranked as the top $13^{\text {th }}$, will be analyzed last, and then compared with the others.

\subsection{SETsquared - UK}

UK is a global leader in the culture industry. According to a DCMS survey in 2016, the country generated $f$ 19.8 billion of creative services exports in 2014, equivalent to roughly 9 percent of all UK exports. The capital of the country, London, is considered the first Creative City according to the Creative City Index. In addition, the UK stands out for innovation, having had between 2006 and 2009 a productivity growth of more than $60 \%$ due to innovation.

SETsquared, named the best incubator in the world by the UBI 2016, does have a great influence on the creative economy, but it is not restricted to it. The incubator emerged as a partnership between the universities of Bath, Bristol, Exeter, Southampton and Surrey, specializing in the growth of high tech start-ups through its incubation program and other acceleration services. SETsquared provides guidance, access to investors and corporate innovators, and industry experts through its network and training program.

The incubator has, among its incubated companies, several that belong to the creative economy, such as 3D Metal Printing, which works with 3D metal printing and Farrow Creative Limited, a multidisciplinary design agency. In addition, SETsquared also promotes creative economy events and workshops.

\subsection{Innovation Incubation Center at Chaoyang University of Technology - Taiwan}

The development of the creative economy in Taiwan occurred mainly from 2009, when the government included 
the creative industry as "emerging industries." Since then, there has been a great development of the area due to the support provided and, in 2013, the industry consisted of about 62 thousand commercial establishments with a combined annual revenue of NT \$ 785.6 billion (US $\$ 24.2$ billion).

Faced with the growth of the creative industry, in September 2015 the Ministry of Culture launched another investment of US $\$ 61.5$ million, with funding from the National Development Fund. The Innovation Incubation Center at Chaoyang University of Technology, in turn, is highly aligned with the government's proposals. Since 2010, the incubator has focused on incubating companies in the areas of design, education and lifestyle with cultural and creative aspects, hoping that these three sectors work in a mutually complementary way to strengthen the production and style of the other areas. One of the objectives of the incubator is to stand out in the creative industry and be an example in Taiwan and the world.

\subsection{The DMZ - Ryerson University (Canada) e Innovate Calgary (Canada)}

Canada has been steadily increasing its share of the creative industry. In 2016 the country signed an agreement with China, Ireland, New Zealand and Jordan to co-produce in the area. Until then the government was not very active in incentives in the area; however, due to the great growth of the creative economy worldwide and within the country, this reality has changed. In order to invest in the area, the country became the first outside of Europe to join Eurolmages, the Council of Europe's film co-production fund. In 2017, it was announced by Minister Joly that the Canadian Music Fund and the Book Fund of Canada would receive $\$ 4.15$ million and $\$ 1$ million, respectively, to promote Canadian creators in foreign markets through tours, marketing, showcases and access to events to get Canadian artists in front of International audience.

The DMZ incubator, created in 2010, is an incubator for technology startups. It being considered as the third best incubator in the world by the UBI index demonstrates that the creative economy has excelled in Canada. DMZ was created by a partnership between the Canadian universities Ryerson University and Innovate Calgary. The aim is to help students and recent graduates improve their business skills and learn how to market their content and creative and digital concepts.

\subsection{1 - United States}

More and more the creative economy has a leading part in the United States. In 2013, artistic and cultural production contributed US $\$ 704.2$ billion to the US economy, an increase of $32.5 \%$ since 1998 , equivalent to $4.23 \%$ of US GDP. In addition, also in 2013 the sector employed 4.7 thousand people, generating 339 billion dollars of income (NEA, 2016).

Founded in 2012, the incubator 1871 has currently more than 400 early-stage and high-growth digital startups. However, of the assets, only 2 have their primary product in the field of arts, which is one of the specific areas of the creative economy (EY, 2014).

\subsection{PoliHub Startup District and Incubator - Italy}

According to research carried out by EY7 in 2014, the creative economy composes $2.9 \%$ of the Italy's GDP, equivalent to 24 billion euros and more than one million employees.

PoliHub Startup District and Incubator's mission is to support innovative startups through cross-fertilization between academia, other startups, and established, high-innovation companies. The incubator is ground-breaking in the area of creative economics, and it is recognized for being able to convert high technology into culture, creativity and social innovation.

\subsection{INiTS Universitäres Gründerservice Wien GmbH - Austria}

In Austria, the creative economy has been growing mainly since 2008, when the Federal Ministry of Science, Economy and Research developed strategies to promote innovation in the creative sector. Because of this, the country stands as one of the pioneers in recognizing the importance of creative policy for the development of technology, industry and innovation.

INiTS operates on three fronts: Information and Communication Technology, Scientific Life, and Other Technologies. In this way, the incubator does not act directly with creative economics. However, many of the incubated companies are from the technology area of the creative field. One example is PhonicScore, which turns the tablet into a high-tech device for music support, and VPlay, which creates games for smartphones and computers ${ }^{1}$.

1 Creative-Industries Strategy for Austria. Available at: https:// www.en.bmdw.gv.at/Innovation/Innovationandtechnologypoli- 


\subsection{ATP Innovations - Australia}

Australia recognizes itself as a country that values the creative industries. They stand out in several of the branches that make up the creative economy, such as the visual arts, documentaries and films. In addition, they recognize its importance in music and in several other sectors. Currently more than half of Australians work in the creative industry; jobs in the industry have grown from 463,000 in 2006 to 531,000 in 2011. From 2006 to 2011, the average annual growth rate of creative employment was $2.8 \%$ while the rest of the workforce grew by only $2 \%^{2}$.

However, despite the great prominence of the creative economy in Australia, ATP Innovations, which is considered the seventh best incubator in the world according to UBI's, focuses mainly on the technology sector. Created in 2000 by the union of four Australian universities (Sydney University of Technology, University of Sydney, University of New South Wales and Australian National University), the incubator has a portfolio of more than 70 startups.

\subsection{YES! Delft and UtrechtInc - Netherlands}

The creative economy has a special role in the Netherlands with an annual net worth of $\$ 12.8$ billion in the creative industry. The creative industry in the Netherlands has a good reputation and ranks among the 10 best in the world for trade, jobs and brands ${ }^{3}$.

Since the 1990s, the Netherlands has grown its creative economy mainly with the TomTom Giant GPS navigators, and with the famous Booking.com. The year of 2006 was a turning point in the development of the country's startup ecosystem, with the celebration of the first edition of the TNW Conference, a meeting that brings together advanced technology leaders with investors. In 2014, the public initiative launched by the government showed strong support for the coordinating, in order to support and promote Dutch startups outside their borders.

The two incubators, YES! Delf and Utrechtlnc, demonstrate the importance of the creative economy in the Netherlands. A YES! Delft Creative is a joint initiative between the government and the Technology University of Delf and aims to provide university students and graduates the opportunity to invest in their ideas with technical

cies/Seiten/default.aspx

2 Why Creative Agencies Are Flocking to Holland. Available at: https://investinholland.com/creative-agencies-flocking- holland/

3 Australia's Creative Economy Surges. Available at: http://www. cci.edu.au/node/1457 assistance ${ }^{4}$. The Utrechtlnc business incubator, accelerates the growth of early-stage startups during their early years of existence. Although it does not focus on the creative economy, the 2016 UtrechtInc created a creative hub, "the Garage", which shows the importance of the creative economy in the incubator ${ }^{5}$.

\subsection{Uppsala Innovation Center - Sweden}

In its business and political communities, Sweden has seen a growing focus on the role of culture and creativity as economic forces. The sector contributed to Sweden's GDP with $3.3 \%$.

The Uppsala Innovation Center is a business incubator that offers well-defined processes to help developing companies to expand their innovations. It has supported more than 30 startups in the design and fashion industry. Additionally, a research group of the Cultural and Creative Economy in Uppsala focuses on how the cultural economy is progressing by means of business and the region.

\subsection{Huazhong University of Science and Technology National Science Park -China}

In China in 2001, a strategy issue in cultural industries was developed in the Tenth Five Year Plan. The political concept of "creative industries" was introduced in 2004 in cities such as Beijing, Shanghai, Shenzhen, and Guangzhou. Most recently, the administration of the largest Hangzhou Xihu district invested in the industry and also launched a fund dedicated to financing small and medium-sized cultural enterprises ${ }^{7}$.

The main industries that are under development by HUST are high tech and science.

4 The creative production and consumption milieu. Creative City Challenge. 2010. Available at: http://archive.northsearegion.eu/ files/repository/20100816174712_CCC6.1.2FrameworkReport.pdf

5 UtrechtInc opens creative hub, the Garage. 2016. Utrechtlnc. Available at: http://news.utrechtinc.nl/131580-utrechtincopens-creative-hub-the-garage

6 The cultural and creative sectors in Sweden. 2014. Volante Research. Available at: http://volanteresearch.com/2014/01/thecultural-and-creative-sector-in-sweden/

7 Detailed Information About Huazhong University of Science and Technology. CUCAS. Available at; http://www.cucas.edu. cn/studyinchina/admission/Huazhong_University_of_Science_ and_Technology_72_97.html 


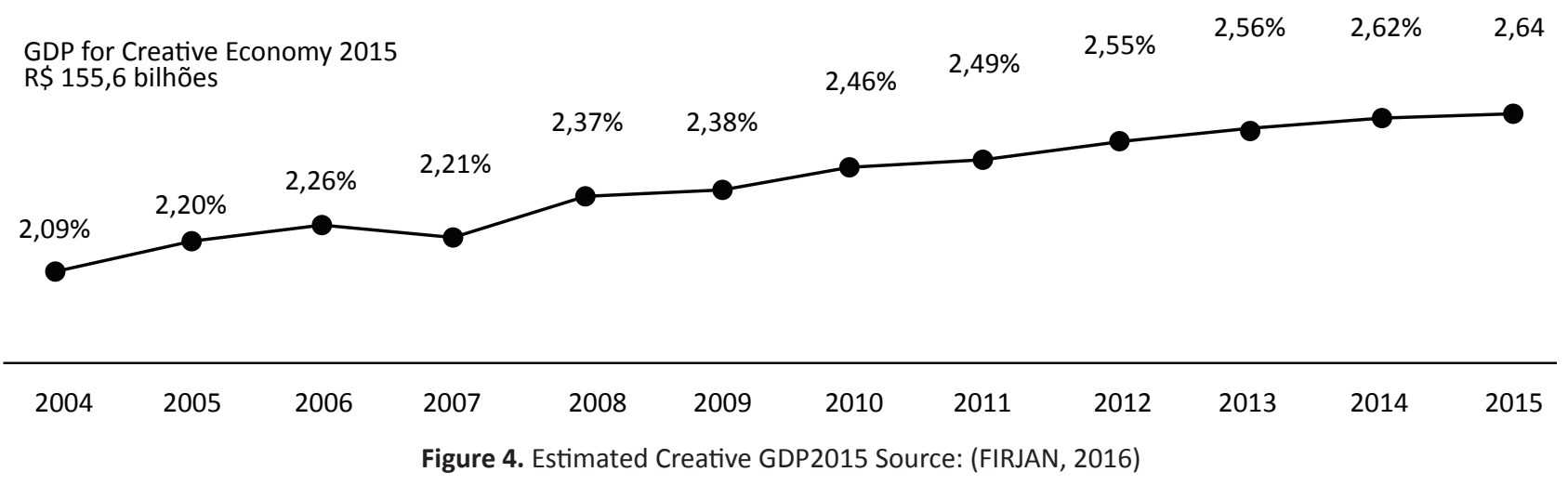

\subsection{Genesis Institute (top 13): The Brazilian Case}

In Brazil, the sectors that compose the creative economy have started to stand out more in the last 15 years. That can be seen as the share of the Creative Economy in the Brazilian GDP, which, in 2004, accounted for only $2.09 \%$ of total GDP and rose to $2.84 \%$ by 2015 .

The number of professionals in the creative industry has also risen. Comparing the years 2004 and 2013, it is possible to observe a growth from 469.8 thousand to 892.5 thousand professionals, which indicates a growth of $90 \%$ in the area, $46 \%$ higher than the increase achieved by the Brazilian working market as a whole (FIRJAN, 2014).

Due to the emerging creative economy, the Brazilian incubators have been living a change in the areas that they act within, tending to increase the level of activity they dedicate to the sectors related to the creative economy.

A study by Zardo (2017), which analyzed 28 incubators and accelerators in Rio de Janeiro, one of the known cities for its creative market, shows that $51.3 \%$ of the incubators support enterprises related to the creative economy, and that of all the incubators generated after 2007, almost all aim to support creative enterprises.

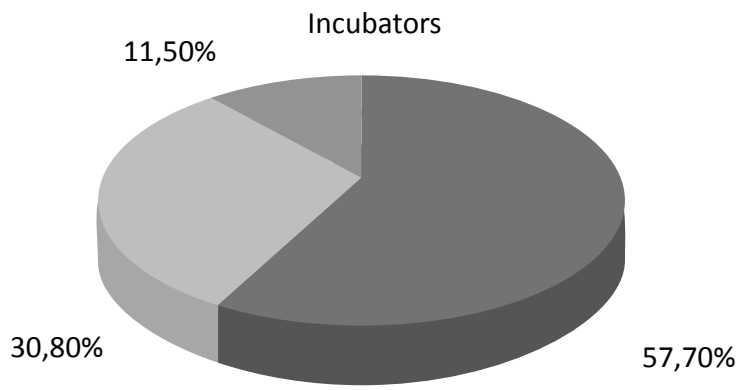

DCE - Doesn't work with Creative Economy MCE - Mixed, also workd with Creative Economy CE - Creative Economy

Graph 1. Incubators according to its actuating areas in 2016 Source: Zardo, 2017
According to Zardo (2017), although the percentage of incubators that act in the creative economy sectors is larger among newer ones rather than older ones, even those which are oldest have to adapt, since the area has been rising in the market.

One example is the top $13^{\text {th }}$ incubator according to UBI, the Genesis Institute. Founded in 1997, the Genesis Institute was created as a support to the Technological Institute (ITUC) of PUC-Rio. Initially focusing solely on the technological areas, its first objective was to guide and provide support to the generation of technological enterprises inside the university.

The purpose of the Institute was not only to make PUCRio the first entrepreneurial university in the country, but also to support undergraduate engineering students who had many questions about their professional careers. In 2002, the creative area was incorporated into the Institute, forming the first cultural incubator in Latin America. Finally, in 2005, the social sector was created. In 2008, the three incubators of the Genesis Institute merged into a single one, building the multisector feature that currently constitutes it. In 2009, Genesis sponsored Rio Criativo (Creative Rio), the main incubator for those in the creative economy for the State of Rio de Janeiro. The incubator of the Gênesis Institute provides several services, including networking, financial and legal support and also a physical space for what may be needed. Currently, among the 25 Germinated and Incubated companies, five startups work directly with Creative Economy, and certainly others use the knowledge generated by its work in order to improve their products. In addition, among the 138 companies which have gone through the Institute, both incubated and germinated, 38 are from the creative area, corresponding to a total of $42 \%$ of incubator enterprises.

Given the broad role of the creative economy within the Genesis Institute, considered the $13^{\text {th }}$ best incubator in the world, and the increase in the number of professionals in related areas, the growing importance of the creative economy in Brazil is evident. 


\section{CONCLUSION}

According to the information compiled, it is possible to observe that most of the top 13 incubators, according to UBI Index 2016, have creative economy as a strong pillar. Even the ones that did not start investing in it have gone through changes and nowadays invest in these economic sectors, by elaborating hubs and coworking or incorporating startups that have one or more of the subsectors of the creative economy as the main basis of their products.

In general, the incubators analyzed work directly with the creative economy or with technology, which is, nevertheless, somehow connected with creative economy. Beyond that, there are incubators that still do not focus on the creative economy, as the Huazhong University of Science and the Technology National Science Park in China, ATP Innovations in Australia, and The DMZ - Ryerson University and Innovate Calgary, both in Canada. Still, these countries are investing on it, and this sector is rising. One example is Australia, which had an enormous growth in the jobs in the creative economy from 2006 until 2011, even surpassing the job growth in other areas.

As it can be seen, therefore, the rise of the creative economy is not only occurring in Brazil, but all over the world. Due to that, it can be concluded that the creative economy is currently a key element for innovation and that all incubators are beginning to integrate it and increase the importance of this area in their work.

\section{REFERENCES}

CityLab (2015), The Global Creative Economy Is Big Business, available at: https://www.citylab.com/life/2015/12/ the-global-creative-economy-is-big-business/422013/

Drucker, P. (1997), Drucker on Asia: A Dialogue between Peter Drucker and Isao Nakauchi, Butterworth-Heinemann, Oxford, UK.

Etzkowitz, H.; Leydesdorff, L. (2000), The Dynamics of Innovation: From National Systems and 'Mode 2' to a Triple Helix of University-Industry-Government Relations, Research Policy, Vol. 29, No. 2, pp. 109-123.

EY (2014), Creating growth Measuring cultural and creative markets in the EU, EY, Paris, available at: https:// www.ey.com/Publication/vwLUAssets/Measuring_cultural_and_creative_markets_in_the_EU/\$FILE/Creating-Growth.pdf

EY (2015), Cultural Times: The first global map of cultural and creative industries, EY, Paris, available at: http:// www.unesco.org/new/fileadmin/MULTIMEDIA/HQ/ERI/ pdf/EY-Cultural-Times2015_Low-res.pdf
Federação das Indústrias do Estado do Rio de Janeiro - FIRJAN (2016), Mapeamento da indústria criativa no brasil, available at: http://www.firjan.com.br/economiacriativa/download/mapeamento-industria-criativa-sistema-firjan-2016.pdf

Federação das Indústrias do Estado do Rio de Janeiro FIRJAN (2014), Mapeamento da Indústria Criativa no Brasil, FIRJAN, Rio de Janeiro.

GOUV.UK (2001), Creative Industries Mapping, available at: https://www.gov.uk/government/publications/ creative-industries-mapping-documents-2001

GOUV.UK (2016), Creative Industries: 2016 Focus on, available at: https://www.gov.uk/government/statistics/ creative-industries-2016-focus-on

Government of Canada (2017), Promoting Canada's Creative Industries on the World Stage and Seizing the Potential of New International Markets, available at: https:// www.canada.ca/en/canadian-heritage/news/2017/04/ promoting_canadascreativeindustriesontheworldstageandseizingthep.html

Hesmondhalgh, D. (2002), The Cultural Industries, SAGE Publications, USA.

Miranda, P. C.; Aranha, J. A.; Zardo, J. (2009), Creativity: people, environment and culture, the key elements in its understanding and interpretation, Science and Public Policy, Vol. 36, No. 7, pp. 523-35.

National Endowment for the Arts - NEA (2016), Arts and Cultural Production Contributed $\$ 704.2$ Billion to the U.S. Economy in 2013, available at: https://www.arts. gov/news/2016/arts-and-cultural-production-contributed-7042-billion-us-economy-2013

SEBRAE (2017), Economia Criativa, available at: http:// www.sebrae.com.br/sites/PortalSebrae/segmentos/economia_criativa/como-o-sebrae-atua-no-segmento-de-economia-criativa,47e0523726a3c510VgnVCM1000004c 00210aRCRD

Taiwan Business Topics (2015), Cultural and Creative Businesses Thriving in Taiwan, available at: https://topics. amcham.com.tw/2015/12/cultural-and-creative-businesses-thriving-in-taiwan/

The Creative Industries (2018), Five Reasons to choose UK Creative Industries, available at: http://www.thecreativeindustries.co.uk/uk-creative-overview/why-the-uk

Thorsby, D. (2001), Economics and Culture, Cambridge University Press, New York, USA.

UNESCO (2013), Creative Economy Report - Widening Local Development Pathways, available at: http://www. unesco.org/culture/pdf/creative-economy-report-2013. pdf 
United Kingdom Department of Culture, Media and Sport - DCMS (2001), Creative Industries Mapping Document, DCMS, London.

United Nations Conference on Trade and Development - UNCTAD (2008), Creative Economy Report 2008, UNCTAD, Switzerland, available at: http://unctad.org/en/docs/ ditc20082cer_en.pdf

University Business Incubator - UBI Index (2016), available from: http://ubiindex.com/
World Economic Forum (2015), What is creativity worth to the world economy?, available at: https://www.weforum.org/agenda/2015/12/creative-industries-worth-world-economy/

Zardo, J. B. (2017), Impacto dos fatores sociais e culturais em ambientes de inovação da economia criativa, Tese (Doutorado em Programa de Pós-Graduação em Politicas Publicas, Estratégias e Desenvolvimento), Universidade Federal do Rio de Janeiro, Rio de Janeiro.

Received: 22 Feb 2018

Approved: 08 Jul 2018

DOI: 10.14488/BJOPM.2018.v15.n3.a12

How to cite: Zardo, J.; Mello, R. (2018), "Responses from Incubators to the Creative Economy", Brazilian Journal of Operations \& Production Management, Vol. 15, No. 3, pp. 444-452, available from: https://bjopm.emnuvens.com.br/bjopm/article/view/463 (access year month day). 